\title{
Dihydromyricetin induces mouse hepatoma Hepal-6 cell apoptosis via the transforming growth factor- $\beta$ pathway
}

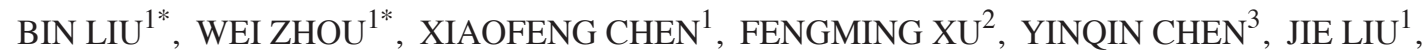 \\ QINGYU ZHANG ${ }^{1}$, SHITING BAO ${ }^{1}$, NIANPING CHEN ${ }^{1}$, MINGYI LI $^{1}$ and RUNZHI ZHU ${ }^{1}$ \\ ${ }^{1}$ Laboratory of Hepatobiliary Surgery, Zhanjiang Key Laboratory of Hepatobiliary Diseases, Guangdong Medical College; \\ Departments of ${ }^{2}$ Pediatrics and ${ }^{3}$ Interventional Medicine, Affiliated Hospital of Guangdong Medical College, \\ Zhanjiang, Guangdong 524001, P.R. China
}

Received January 18, 2014; Accepted August 18, 2014

DOI: $10.3892 / \mathrm{mmr} .2014 .2891$

\begin{abstract}
Dihydromyricetin (DHM) is a flavonoid compound which possesses potent antitumor activity. In the present study, it was demonstrated that DHM significantly inhibited proliferation and induced apoptosis in mouse hepatocellular carcinoma Hepal-6 cells. Transforming growth factor $\beta$ (TGF- $\beta$ ) is recognized as a major profibrogenic cytokine and is therefore a common target for drugs in the treatment of liver disease. The present study aimed to investigate whether TGF- $\beta$ was involved in DHM-triggered cell-viability inhibition and apoptosis induction. An MTT assay was used to evaluate the viability of Hepal- 6 cells following DHM treatment. TGF- $\beta$ signalling is mediated by Smads and nicotinamide adenine dinucleotide phosphate oxidase 4 (NOX4) is a crucial regulator of reactive oxygen species ROS production. TGF- $\beta$, Smad3, phosphorylated (p)-Smad2/3 and NOX4 protein expression levels were evaluated by western blot analysis. TGF- $\beta$ and NOX4 gene expression levels were determined by quantitative polymerase chain reaction. The results indicated that DHM downregulated TGF- $\beta, \operatorname{Smad} 3, \mathrm{p}-\mathrm{Smad} 2 / 3$ and NOX4 in a concentration-dependent manner. A cell counting assay indicated that DHM also inhibited Hepal-6 cell growth in a concentration-dependent manner. TGF- $\beta$ expression was significantly decreased following DHM treatment. In conclusion, the results of the present study defined and supported a novel function for DHM, indicating that it induced cell apoptosis by downregulating ROS production via the
\end{abstract}

Correspondence to: Dr Mingyi Li or Dr Runzhi Zhu, Laboratory of Hepatobiliary Surgery, Zhanjiang Key Laboratory of Hepatobiliary Diseases, Guangdong Medical College, 57 North Ren Min Road, Zhanjiang, Guangdong 524001, P.R. China

E-mail: hepatolab@gmail.com

E-mail: hepatolab@163.com

${ }^{*}$ Contributed equally

Key words: dihydromyricetin, transforming growth factor- $\beta$, Smad3, NADPH oxidase 4, reactive oxygen species
TGF- $\beta /$ Smad3 signaling pathway in mouse hepatocellular carcinoma Hepal-6 cells.

\section{Introduction}

Dihydromyricetin (DHM, $\mathrm{C}_{15} \mathrm{H}_{12} \mathrm{O}_{8}$, PubChem CID: 161557, Fig. 1A) is an active component in extracts of Ampelopsis grossedentata and a biologically active flavonoid compound (1). DHM possesses potent antitumor activity both in vivo and in vitro (2). It has been reported that DHM has numerous pharmacological functions, including anti-inflammatory, antibacterial, cough-relief, antioxidant, antihypertensive, hepatoprotective and anti-cancer effects $(3,4)$. It exerts an antioxidative effect by chelating $\mathrm{Fe}^{2+}(5)$. In addition, it was demonstrated that DHM was able to decrease accumulation of reactive oxygen species (ROS) (6,7). Previous studies have reported significant inhibitory activity of DHM against breast cancer MCF-7 (8) and MDA-MB-231 (9) cells, nasopharyngeal carcinoma HK-1 cells, liver cancer Bel-7402 cells (10), leukemia HL-60 and K-562 cells and lung cancer H1299 cells (11). Based on evidence from previous studies, the present study aimed to elucidate the association between transforming growth factor- $\beta$ (TGF- $\beta$ ) and nicotinamide adenine dinucleotide phosphate oxidase 4 (NOX4) during DHM-induced apoptosis in mouse hepatocellular carcinoma Hepal-6 cells .

Though TGF- $\beta$ was initially suggested to be involved in a tumor supressor pathway due to its cytostatic activity in epithelial cells, further studies have identified TGF- $\beta$ as a pro-tumorigenic factor. The majority of human tumors, including melanoma, secrete significant amounts of TGF- $\beta$, which directly influences the tumor microenvironment, promoting peritumoral angiogenesis as well as tumor cell migration and invasiveness, immune evasion and dissemination to metastatic sites $(12,13)$. TGF- $\beta$ signaling is mediated by TGF-type II (T $\beta$ RII) and type I (T $\beta R I)$ receptors. TGF- $\beta$ binding induces the formation of heteromeric complexes which promote the phosphorylation, and therefore activation, of T $\beta$ RI by T $\beta$ RII. Activated T $\beta$ RI phosphorylates receptor (R)-Smads, including Smad2 and -3 (14). These activated R-Smads form heteromeric complexes with Smad4, which accumulate in the nucleus and regulate target-gene transcription (15). TGF- $\beta$ has been shown to increase NOX4 expression 
in various cell types; however, the localization of NOX4 remains to be elucidated (16). Tobar et al (17) reported that TGF- $\beta$ upregulated NOX4 expression via a factor-induced apoptotic pathway in fetal rat hepatocytes. Furthermore, ROS production in human hepatocyte cell lines previously infected with the hepatitis $\mathrm{C}$ virus depends on NOX4 activity whose expression is stimulated by TGF- $\beta$ (18). Several studies have reported that TGF- $\beta$ promotes NOX4 production of intracellular ROS $(19,20)$. ATP production and biosynthesis of building blocks are required to sustain cellular function and cell viability is functionally coordinated by interlocking regulatory mechanisms that control electron transport in the respiratory chain (21). The present study therefore aimed to investigate whether DHM was able to reduce ATP levels and ROS production via the TGF- $\beta$ signaling pathway in mouse hepatoma Hepal-6 cells.

\section{Materials and methods}

Reagents. DHM was purchased from Sigma (St. Louis, MO, USA) and was dissolved to a concentration of $50 \mathrm{mM}$ in dimethylsulfoxide (DMSO) as a stock solution and stored at $-20^{\circ} \mathrm{C}$. The final DMSO concentration did not exceed $0.1 \%$ DMSO throughout the study. Rabbit antibodies to TGF- $\beta$, TGF- $\beta$ RII, Smad3, phosphorylated (p)-Smad2/3 and GAPDH were obtained from Cell Signaling Technology (Beverly, MA, USA). Goat anti-rabbit immunoglobulin G-horseradish peroxidase (IgG-HRP; EarthOx, Millbrae, CA, USA) was used as the secondary antibody.

Cell culture and DHM treatment. The mouse Hepal-6 cell line was provided by the Maternal and Child Health Hospital of Shanghai (Shanghai, China). Cells were cultured in RPMI-1640 medium supplemented with $10 \%$ (v/v) fetal bovine serum (Gibco-BRL, Invitrogen Life Technologies, Carlsbad, CA, USA), penicillin $100 \mathrm{U} / \mathrm{ml}$ and streptomycin $100 \mathrm{U} / \mathrm{ml}$ (Hyclone, Logan, UT, USA), and maintained in a humidified atmosphere of $95 \%$ air and $5 \% \mathrm{CO}_{2}$ at $37^{\circ} \mathrm{C}$. Hepal- 6 cells were grown in standard media and when the confluency reached 50-60\%, cells were treated with DHM $(10,50$ or $100 \mu \mathrm{M})$ for $48 \mathrm{~h}$.

Measurement of intracellular ROS levels. To detect the accumulation of intracellular ROS in Hepal-6 cells, a ROS assay kit was purchased from BioVision Inc. (Milpitas, CA, USA). Briefly, following treatment of cells with different concentrations of DHM $(10,50$ and $100 \mu \mathrm{M})$ for $48 \mathrm{~h}$ in a $96-w e l l$ plate at a cell density of 2500 cells/well, $100 \mu 1$ 2',7'-dichlorofluorescin diacetate (DCFDA) mix was added and incubated for $45 \mathrm{~min}$ at $37^{\circ} \mathrm{C}$ in the dark, including blank wells (with non-stained cells). The fluorescence intensity was measured using a fluorescence plate reader (EnSpire ${ }^{\mathrm{TM}} 2300$ Multilabel Reader; Perkin Elmer, Inc., Waltham, MA, USA) at excitation/emission $=488 / 525 \mathrm{~nm}$.

Measurement of adenosine triphosphate (ATP) production. Intracellular ATP levels were measured using the ApoSENSOR cell viability assay kit (BioVision) according to the manufacturer's instructions. Briefly, cells were treated with DHM (10, 50 and $100 \mu \mathrm{M}$ ) for $48 \mathrm{~h}$, then incubated with $100 \mu \mathrm{l}$ nuclear releasing reagent for $5 \mathrm{~min}$ at room temperature with gentle shaking, followed by further incubation with $5 \mu \mathrm{l}$ ATP monitoring enzyme. Detection was performed using a luminometer (Sirius L; Titertek-Berthold, Pforzheim, Germany).

Annexin V/propidium iodide (PI) double staining assay. Apoptotic cells werequantified using an Annexin V-fluorescein isothiocyanate (FITC)/PI kit (BioVision) and detected by flow cytometry (FACSCalibur; Becton-Dickinson, BD Biosciences, Franklin Lakes, NJ, USA), and analyzed by Modfit and CellQuest Vida 6.1 software (BD Biosciences). Briefly, cells were pretreated with 10,50 or $100 \mu \mathrm{M}$ DHM for $48 \mathrm{~h}$ and washed with phosphate-buffered saline (PBS). Cells were subsequently collected and resuspended in binding buffer [pH 7.5, $10 \mathrm{mM}$ 4-(2-hydroxyethyl)-1-piperazineethanesulfonic acid, $2.5 \mathrm{mM} \mathrm{CaCl}_{2}$ and $140 \mathrm{mM} \mathrm{NaCl}$. Cells were incubated with Annexin V-FITC and PI for $10 \mathrm{~min}$ in the dark, prior to flow cytometric analysis. In the early stages of apoptosis, cells were Annexin V-positive, whereas Annexin V and PI-positive cells were considered to be in the late stage of apoptosis.

MTT assay. Cell densities were adjusted to $2 \times 10^{4}$ cells $/ 100 \mu 1$. Cells were seeded into a 96 -well plate, which was placed in an incubator overnight to allow for attachment and recovery. Briefly, cells were pretreated with 10,50 or $100 \mu \mathrm{M}$ DHM for $48 \mathrm{~h}$. MTT was dissolved at $5 \mathrm{mg} / \mathrm{ml}$ in warm assay medium and $20 \mu \mathrm{l}$ MTT solution was transferred to each well to yield a final volume of $120 \mu \mathrm{l} /$ well. Plates were incubated for $4 \mathrm{~h}$ at $37^{\circ} \mathrm{C}$ and $5 \% \mathrm{CO}_{2}$. Following incubation, supernatants were removed, and $150 \mu \mathrm{l}$ DMSO was added. The plate was placed on an orbital shaker for $5 \mathrm{~min}$ and subsequently, the absorbance at $595 \mathrm{~nm}$ was recorded with an EnSpire ${ }^{\mathrm{TM}} 2300$ Multilabel Reader (Perkin Elmer, Inc.).

DHM-regulated protein analysis. Cells were collected following DHM treatment and lysed in lysis buffer [100 mM Tris-HCl, pH 6.8, 4\% (m/v) SDS, 20\% (v/v) glycerol, 200 mM 2-mercaptoethanol, $1 \mathrm{mM}$ phenylmethyl sulfonylfluoride, and $1 \mathrm{~g} / \mathrm{ml}$ aprotinin] for $30 \mathrm{~min}$ on ice. The total protein concentrations in the supernatants were detected using a bicinchoninic acid (BCA) assay with the BCA Protein Assay kit purchased from Beyotime Institute of Biotechnology (Haimen, Jiangsu, China). SDS-PAGE was performed using an $8-15 \%$ gradient on standard polyacrylamide gels. Proteins were subsequently transferred to nitrocellulose membranes saturated with 5\% milk in Tris-buffered saline and $1 \%$ Tween-20 (TBST) and incubated with primary antibodies in diluent overnight at $4^{\circ} \mathrm{C}$. The membranes were washed three times with TBST, incubated with anti-rabbit IgG-HRP for $1 \mathrm{~h}$ and washed a further four times with TBST. Detection was performed using the Odyssey Infrared Imaging System (LI-COR Biosciences Inc., Lincoln, NE, USA).

Quantitative PCR (qPCR): Quantification of messenger RNA (mRNA) expression. mRNA expression levels were determined by qPCR using SYBR green. mRNA was reverse-transcribed to cDNA using the PrimeScript RT Reagent kit with the gDNA Eraser kit (Takara Bio, Inc., Otsu, Japan) The following primer sequences were used: 
A<smiles>O=C1c2c(O)cc(O)cc2O[C@H](c2cc(O)c(O)c(O)c2)[C@H]1O</smiles>

B
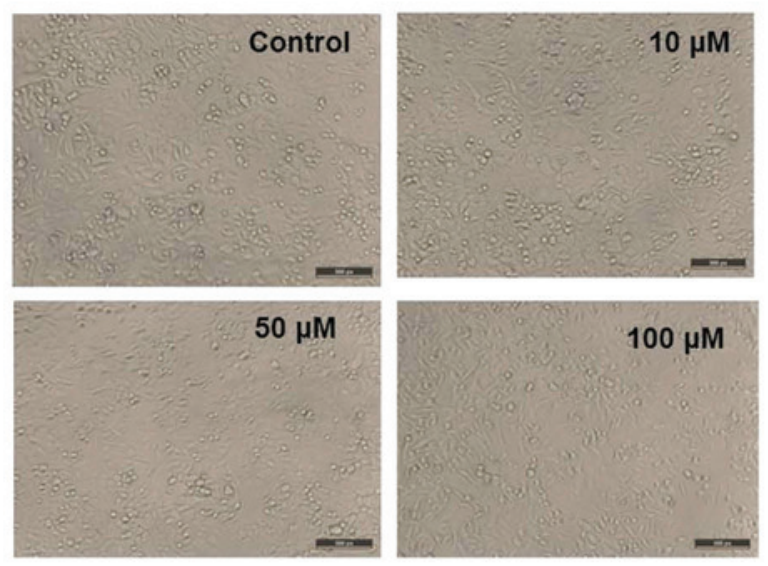

D

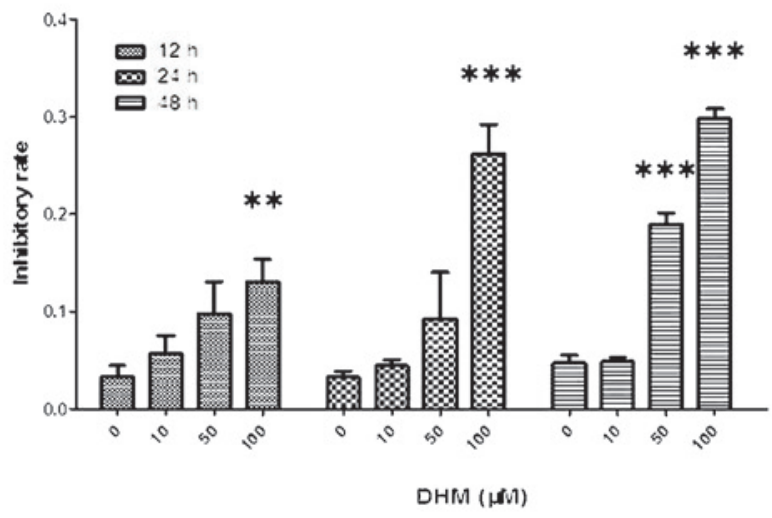

Figure 1. DHM induces cell growth inhibition and apoptosis in Hepal-6 cells. (A) Chemical structure of DHM. (B) DHM induced cell proliferation in Hepal-6 at various concentrations (10, 50 and $100 \mu \mathrm{M})$ for $48 \mathrm{~h}$, visualized by microscopy (magnification, x100). (C) Hepal-6 cells were treated with various concentrations $(10,50$, or $100 \mu \mathrm{M})$ of DHM for $48 \mathrm{~h}$ and the results were analyzed by flow cytometry. Each sample was measured in duplicate, and the figure is a representative of three independent assays. (D) MTT assay analyzed cell growth inhibition rates in cells treated with different concentrations (10, 50 and $100 \mu \mathrm{M}$ ) of DHM for $12,24,48 \mathrm{~h}$. Values are expressed as the mean \pm standard deviation of three independent experiments. ${ }^{* *} \mathrm{P}<0.01$, ${ }^{* * *} \mathrm{P}<0.001$ vs. $0 \mu \mathrm{M}$ DHM. DHM, dihydromyricetin; FITC, fluorescein isothiocyanate; PI, propidium iodide; A, area.

18S forward, 5'-CGGCGACGACCCATTCGAAC-3' and reverse, 5'-GAATCGAACCCTGATTCCCCGTC-3'; TGF- $\beta$ forward, 5'-GGACTACTATGCTAAAGAGGTCAC-3' and reverse, 5'-CTGTATTCCGTCTCCTTGGTTCAGC-3'; NOX4 forward, 5'-GTTCGGCACATGGGTAAAAG-3' and reverse, 5'-ACCAAGGGCCAGAGTATCAC-3'. Total RNA was prepared using TRIzol reagent (Invitrogen Life Technologies, Carlsbad, CA, USA). qPCR was performed with the MJ chromo 4 RT-PCR detection system (Bio-Rad Laboratories, Hercules, CA, USA). The expression levels of the housekeeping gene $18 \mathrm{~S}$ were measured as an internal control.

Statistical analysis. All values are presented as the mean \pm standard deviation from triplicate experiments performed in a parallel manner unless otherwise indicated. Statistical differences were evaluated using Student's t-test. $\mathrm{P}<0.05$ was considered to indicate a statistically significant difference between values. All figures exhibited in the present study are representative of $\geq$ three independent experiments.

\section{Results}

DHM inhibits proliferation and promotes apoptosis of Hepal-6 cells. Untreated Hepal-6 cells grew normally with clear skeletons, whereas the morphology of cells treated with DHM was distorted, some became round and the number of sloughed cells increased in a dose-dependent manner (Fig. 1B). The rate of cell apoptosis also increased in a concentration-dependent manner (Fig. 1C). The results of the MTT assay demonstrated that DHM inhibited cell growth in a time- and concentration-dependent manner in Hepal-6 cells following 12, 24 and $48 \mathrm{~h}$ treatment (Fig. 1D). These data revealed that DHM exerted a significant inhibitory effect on the viability of Hepal-6 cells, which may contribute to its anti-tumor potency. In cells treated with $50 \mu \mathrm{M}$ DHM cell growth was inhibited and the majority of Hepal-6 cells underwent apotosis ( $\mathrm{IC}_{50}$ of DHM on Hepal-6 cells was $190 \mu \mathrm{M}$ for $48 \mathrm{~h}$ treatment). These results demonstrated that DHM inhibited proliferation and promoted apoptosis in Hepal- 6 cells in a time- and concentration-dependent manner. 
A

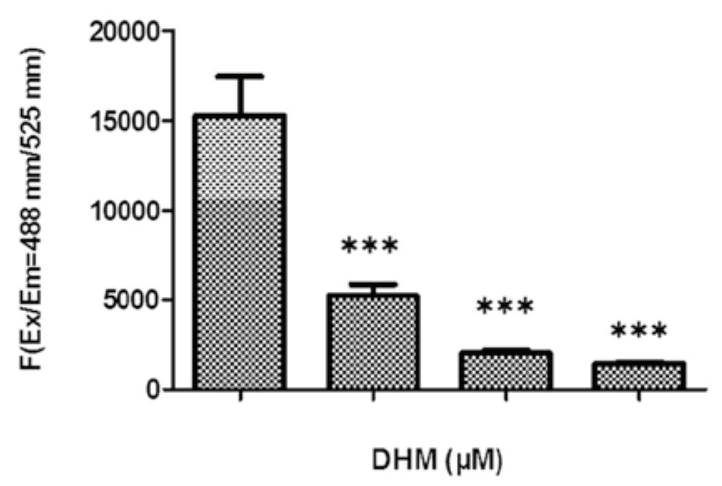

B

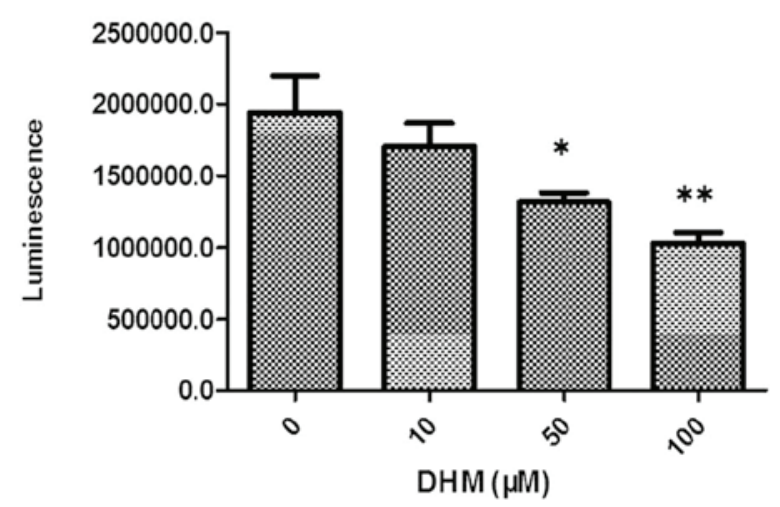

Figure 2. DHM decreases ROS and ATP in Hepal-6 cells. (A) Intracellular levels of ROS were detected following $48 \mathrm{~h}$ treatment with DHM (10, 50 and $100 \mu \mathrm{M})$. (B) Intracellular levels of ATP were detected following $48 \mathrm{~h}$ treatment with DHM $(10,50$ and $100 \mu \mathrm{M}) .{ }^{*} \mathrm{P}<0.05 ;{ }^{* * *} \mathrm{P}<0.01 ;{ }^{* * * *} \mathrm{P}<0.001$ vs. $0 \mu \mathrm{M}$ DHM. DHM, dihydromyricetin; ROS, reactive oxygen species; ATP, adenosine triphosphate.

$\mathbf{A}$

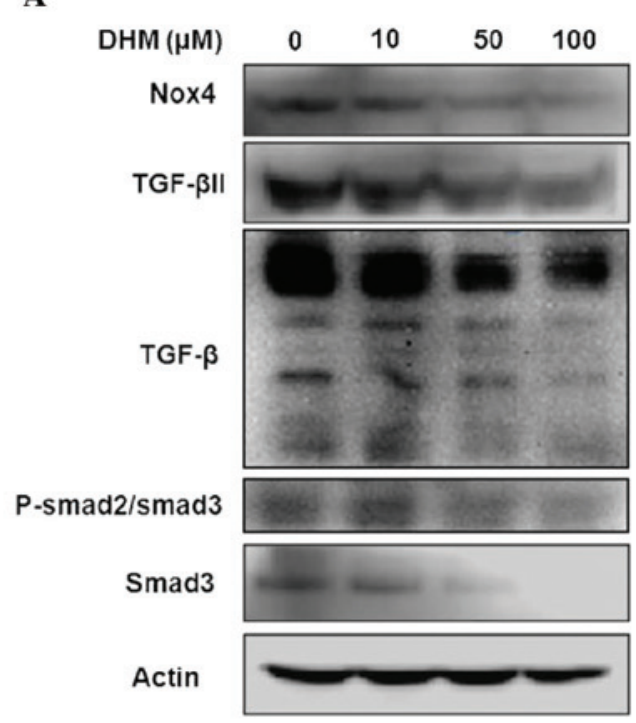

C

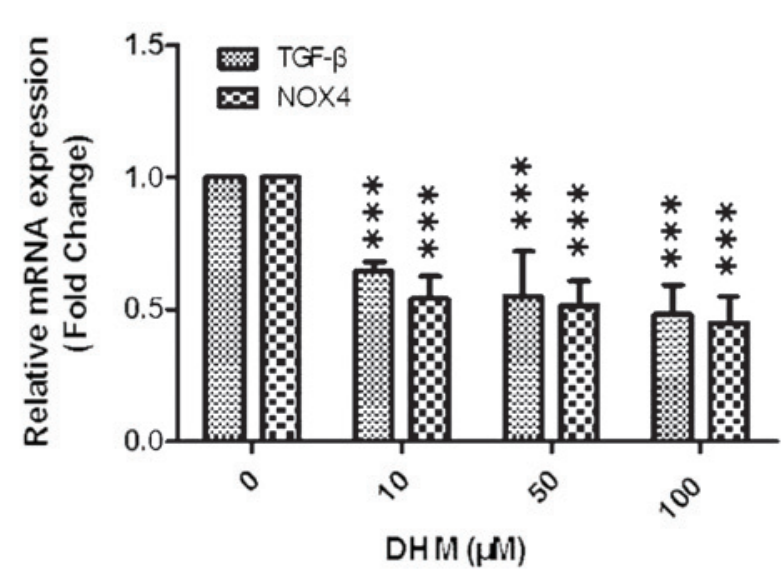

D
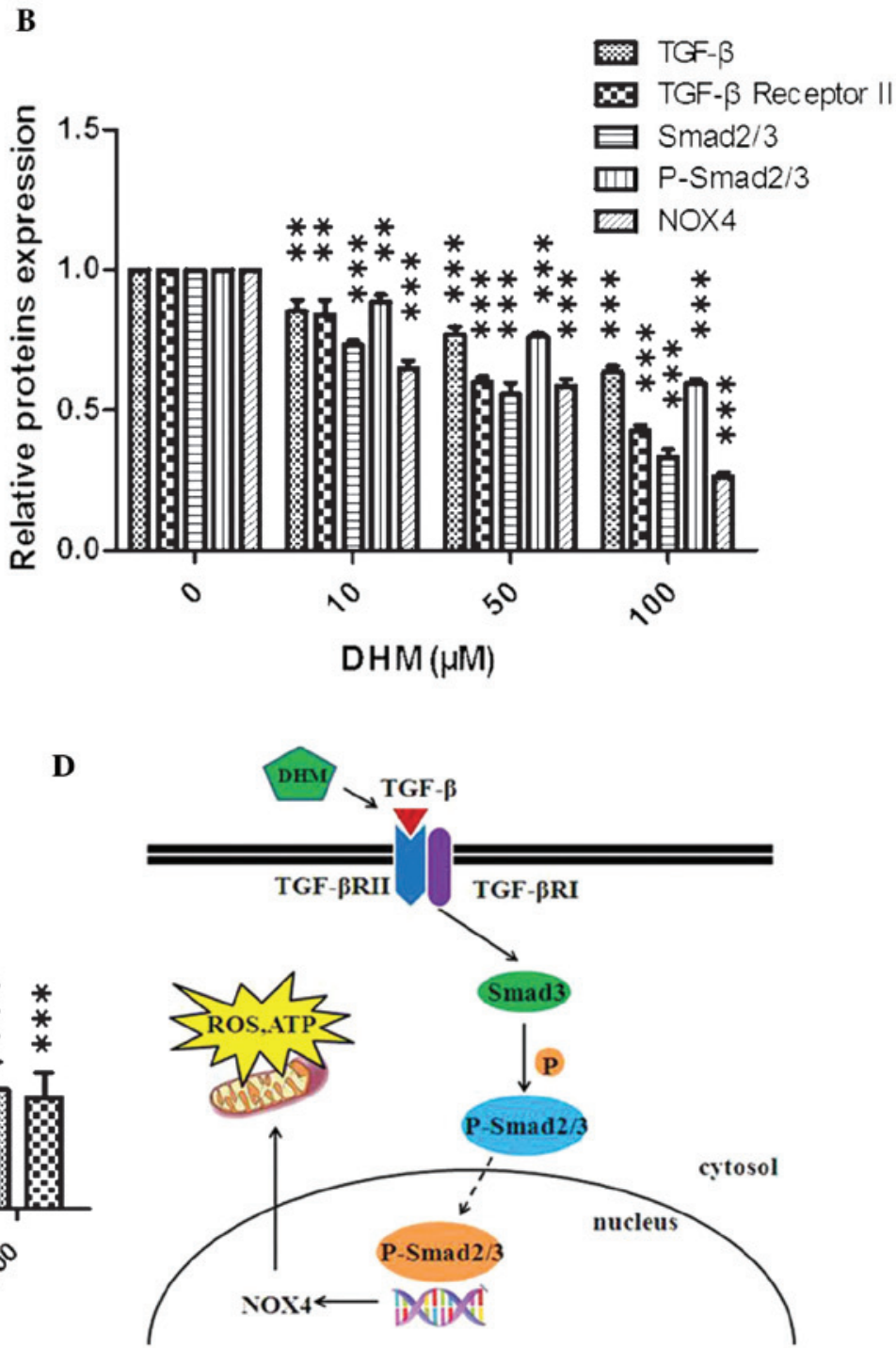

Figure 3. Western blot analysis of the effects of DHM on mRNA and protein expression levels in Hepal-6 cells. (A) Western blot analysis of cells treated with various concentrations $(10,50$ and $100 \mu \mathrm{M})$ of DHM for $48 \mathrm{~h}$ (representative of three independent experiments). (B) Column diagram for A. (C) Cells were treated with DHM $(10,50$ and $100 \mu \mathrm{M})$ for $24 \mathrm{~h}$ and TGF- $\beta$ and NOX4 mRNA expression were measured by quantitative polymerase chain reaction. The experiment was performed in triplicate. ${ }^{* *} \mathrm{P}<0.01,{ }^{* * *} \mathrm{P}<0.001$ vs. $0 \mu \mathrm{M}$ DHM. Values are expressed as the mean \pm standard deviation (D) Schematic of the suggested mechanism of action of DHM. DHM, dihydromyricetin; mRNA, messenger RNA; NOX4, NADPH oxidase 4; TGF- $\beta$, transforming growth factor- $\beta$; ROS, reactive oxygen species; ATP, adenosine triphosphate; TGF- $\beta$ R, transforming growth factor- $\beta$ receptor; $p$, phosphorylated. 
DHM reduces ROS production in Hepal-6 cells. The levels of ROS in Hepal-6 cells treated with various concentrations of DHM for $48 \mathrm{~h}$ were evaluated. The cell-permeant DCFDA, which is oxidized to green fluorescent 2',7'-dichlorofluorescein by various peroxide-like ROS and nitric oxide-derived reactive intermediates, was used as a probe. These data demonstrated that DHM significantly decreased ROS production in Hepal-6 cells, and that this ROS imbalance may promote mitochondrial dysfunction and trigger mitochondria-mediated apoptosis. Intracellular levels of ROS in cells treated with 10,50 and $100 \mu \mathrm{M}$ DHM decreased in a concentration-dependent manner, compared with those in vehicle-treated cells (Fig. 2A).

DHM decreases intracellular ATP expression levels in Hepal-6 cells. In order to examine whether DHM caused a dysfunction of mitochondrial energy, intracellular levels of ATP in DHM-treated cells were investigated. Cells were treated with various concentrations of DHM for $48 \mathrm{~h}$ and the results indicated that the intracellular levels of ATP were markedly decreased in a concentration-dependent manner (Fig. 2B).

DHM downregulates TGF- $\beta$ and NOX4. In the present study, cells were treated with 10,50 or $100 \mu \mathrm{M}$ DHM for $24 \mathrm{~h}$ and mRNA expression levels of TGF- $\beta$ and NOX4 were evaluated by qPCR. Cells were also treated with 10,50 or $100 \mu \mathrm{M}$ DHM for $48 \mathrm{~h}$ and TGF- $\beta$, TGF- $\beta$ II, Smad3, p-Smad2/3 and NOX4 protein expression levels were evaluated by western blot analysis. The results indicated that TGF- $\beta$ and NOX4 mRNA expression levels decreased, and that protein expression levels of TGF- $\beta$, TGF- $\beta$ II, Smad3, $\mathrm{p}-\mathrm{Smad} 2 / 3$ and NOX4 were reduced in a concentration-dependent manner (Fig. 3A-C).

\section{Discussion}

Western blot analysis was performed in order to measure TGF- $\beta$, TGF- $\beta$ RII, Smad3, p-Smad $2 / 3$ and NOX4 protein expression levels, while qPCR analysis was used to measure TGF- $\beta$ and NOX4 mRNA expression levels. The results demonstrated that DHM decreased TGF- $\beta$ and NOX4 mRNA expression levels in cells treated with DHM for $24 \mathrm{~h}$ and furthermore, induced a reduction in TGF- $\beta$, TGF- $\beta$ RII, Smad3, p-Smad2/3 and NOX4 protein expression levels in a concentration-dependent manner. It was further demonstrated that DHM induced a decrease in ROS and ATP production in a concentration-dependent manner. The TGF- $\beta$ signaling pathway is involved in multiple cellular processes, including cell growth, differentiation, adhesion, migration and apoptosis. T $\beta$ RI, T $\beta$ RII and intracellular mediators, including Smad proteins, mediate TGF- $\beta$ signaling $(22,23)$. The binding of TGF- $\beta$ to T $\beta$ RII induces phosphorylation of $\mathrm{T} \beta \mathrm{RI}$ at glycine-serine repeats in the cytoplasmic tail domain by T $\beta$ RII, leading to T $\beta$ RI activation (24). At present, it is hypothesized that the Smad complex remains associated and is actively involved in transcriptional regulation $(25,26)$. A previous study demonstrated that Smad3 and -4 had important roles in TGF- $\beta$-induced epithelial to mesenchymal transition and breast cancer metastasis (27). It was reported that abrogation of the Smad pathway in M4 cells by using a dominant negative Smad3 mutant or via overexpression of a Smad-binding defective T $\beta$ RI mutant suppressed metastasis $(28,29)$.

Cancer progression has been associated with oxidative stress (30). Loss of TGF- $\beta$ signaling in mammary carcinoma cells increased the abundance of smooth muscle actin-positive stroma and enhanced tumor cell survival and heterogeneity (31-33). A study by Giannelli et al (34) indicated that the inhibition of TGF- $\beta$ signalling resulted in numerous downstream effects, which may improve clinical outcomes in hepatocellular carcinoma treatment. Furthermore, it has been demonstrated that ROS production in human hepatocyte cell lines previously infected with the hepatitis $\mathrm{C}$ virus depends on NOX4 activity, whose expression is stimulated by TGF- $\beta$ (18). Superoxide and hydrogen peroxide, which are redox signaling molecules involved in various cellular functions, are major producers of ROS (35). Redox imbalance occurs due to excessive or insufficient ROS production and is a pathophysiological induction factor for numerous pathological conditions, including cancer development and progression. It has previously been demonstrated that, apart from mitochondria, the nicotinamide adenine dinucleotide phosphate oxidase complex is the most significant intracellular source of ROS (36). NOX4 expression has been demonstrated to be regulated by differentiating factors including TGF- $\beta$, as observed in the present study (37). It was also reported that TGF- $\beta 1$-stimulated expression of NOX4 resulted in the oxidation of mitogen-activated protein kinase phosphatase-1, which led to the factor-dependent modification of gene expression in murine fibroblasts (38). Several studies have reported that TGF- $\beta$ induces NOX4 to generate intracellular ROS $(19,39)$. Smad3-mediated gene transcription has an important role in the induction of NOX4 expression following TGF- $\beta$ stimulation (40).

In conclusion, the present study revealed that DHM induced a reduction in TGF- $\beta$, TGF- $\beta$ RII, Smad3, p-Smad $2 / 3$ and NOX4 protein expression levels, as well as a reduction in ROS and ATP production in Hepal-6 cells. Conventional anti-cancer drugs induce cancer cell apoptosis by elevating ROS; however this results in significant damage to normal cells. DHM enhanced the rate of apoptosis in Hepal-6 cells, whilst reducing ROS levels. This means that DHM may be capable of exerting anti-cancer effects whilst causing minimal damage to normal cells. Further studies are required to elucidate the potential of DHM to be used as an anti-cancer drug.

\section{Acknowledgements}

This work was supported in part by the following grants: Guangdong Province Natural Science Funds (no. S2011010003750), Zhanjiang 2012 Annual Financial Capital Competitive Project Science and Technology Project (no. 2012C0302-52) and Guangdong Medical College Scientific Research Fund project (no. M2013012).

\section{References}

1. Wu S, Liu B, Zhang Q, et al: Dihydromyricetin reduced Bcl-2 expression via p53 in human hepatoma hepg2 cells. PLoS One 8: e76886, 2013. 
2. Li H, Li Y, Zhang Y, Shi H, Hu W and Zhang Z: Comparison of refluxing, ultrasonic-and microwave-assisted extraction of dihydromyricetin from Ampelopsis grossedentata. J AOAC Int 91: 1278-1283, 2008.

3. Ye J, Guan Y, Zeng S and Liu D: Ampelopsin prevents apoptosis induced by $\mathrm{H} 2 \mathrm{O} 2$ in MT-4 lymphocytes. Planta Med 74: 252-257, 2008.

4. Kundaković K, Stanojković T, Milenković M, Grubin J, Juranić Z, Stevanović B and Kovačević N: Cytotoxic, antioxidant, and antimicrobial activities of Ampelopsis brevipedunculata and Parthenocissus tricuspidata (Vitaceae). Arch Biol Sci 60: 641-647, 2008

5. Zhou Y, Shu F, Liang X, et al: Ampelopsin induces cell growth inhibition and apoptosis in breast cancer cells through ROS generation and endoplasmic reticulum stress pathway. PLoS One 9: e89021, 2014.

6. Kou X, Shen K, An Y, Qi S, Dai WX and Yin Z: Ampelopsin inhibits $\mathrm{H}_{2} \mathrm{O}_{2}$-induced apoptosis by ERK and Akt signaling pathways and up-regulation of heme oxygenase- 1 . Phytother Res 26: 988-994, 2012.

7. Qi S, Xin Y, Guo Y, Diao Y, Kou X, Luo L and Yin Z: Ampelopsin reduces endotoxic inflammation via repressing ROS-mediated activation of $\mathrm{PI} 3 \mathrm{~K} / \mathrm{Akt} / \mathrm{NF}-\kappa \mathrm{B}$ signaling pathways. Int Immunopharmacol 12: 278-287, 2012

8. Jeon SH, Chun W, Choi YJ and Kwon YS: Cytotoxic constituents from the bark of Salix hulteni. Arch Pharm Res 31: 978-982, 2008

9. Zhou FZ, Zhang XY and Guo Y: Anti-proliferation effect of combining dihydromyricetin and adriamycin on MDA-MB-231 cell in vitro. Journal of Hubei University for Nationalities (Medical Edition) 4: 001, 2010.

10. Guo X, Zhu K, Zhang H and Yao H: Anti-tumor activity of a novel protein obtained from tartary buckwheat. Int J Mol Sci 11: 5201-5211, 2010.

11. Zhang QY, Li R, Zeng GF, et al: Dihydromyricetin inhibits migration and invasion of hepatoma cells through regulation of MMP-9 expression. World J Gastroenterol 20: 10082-10093, 2014.

12. Busse A and Keilholz U: Role of TGF- $\beta$ in melanoma. Curr Pharm Biotechnol 12: 2165-2175, 2011.

13. Perrot CY, Javelaud D and Mauviel A: Insights into the transforming growth factor- $\beta$ signaling pathway in cutaneous melanoma. Ann Dermatol 25: 135-144, 2013.

14. Moustakas A, Souchelnytskyi S and Heldin CH: Smad regulation in TGF-beta signal transduction. J Cell Sci 114 (Pt 24): 4359-4369, 2001

15. Varelas X,Samavarchi-Tehrani P,Narimatsu M, et al: The Crumbs complex couples cell density sensing to Hippo-dependent control of the TGF- $\beta$-SMAD pathway. Developmental cell 19: 831-844, 2010.

16. Brown DI and Griendling KK: Nox proteins in signal transduction. Free Radic Biol and Med 47: 1239-1253, 2009.

17. Tobar N, Guerrero J, Smith PC and Martínez J: NOX4-dependent ROS production by stromal mammary cells modulates epithelial MCF-7 cell migration. Br J Cancer 103: 1040-1047, 2010.

18. Boudreau HE, Emerson SU, Korzeniowska A, Jendrysik MA and Leto TL: Hepatitis C virus (HCV) proteins induce NADPH oxidase 4 expression in a transforming growth factor $\beta$-dependent manner: a new contributor to $\mathrm{HCV}$-induced oxidative stress. J Virol 83: 12934-12946, 2009.

19. Barnes JL and Gorin Y: Myofibroblast differentiation during fibrosis: role of NAD(P)H oxidases. Kidney Int 79: 944-956, 2011.

20. Liu R-M and Gaston Pravia K: Oxidative stress and glutathione in TGF- $\beta$-mediated fibrogenesis. Free Radical Biology and Medicine 48: 1-15, 2010.

21. Pike LS, Smift AL, Croteau NJ, Ferrick DA and Wu M: Inhibition of fatty acid oxidation by etomoxir impairs NADPH production and increases reactive oxygen species resulting in ATP depletion and cell death in human glioblastoma cells. Biochim Biophys Acta 1807: 726-734, 2011

22. Kisseleva $\mathrm{T}$ and Brenner DA: Mechanisms of fibrogenesis. Exp Biol Med (Maywood) 233: 109-122, 2008.

23. Pérez-Gómez E, Del Castillo G, Santibáñez JF, Lopez-Novoa JM, Bernabéu C and Quintanilla M: The role of the TGF- $\beta$ coreceptor endoglin in cancer. Scientific World Journal 10: 2367-2384, 2010.
24. Baek HJ, Pishvaian MJ, Tang Y, Kim TH, Yang S, Zouhairi ME, Mendelson J, Shetty K, Kallakury B, Berry DL, et al: Transforming growth factor- $\beta$ adaptor, $\beta 2$-spectrin, modulates cyclin dependent kinase 4 to reduce development of hepatocellular cancer. Hepatology 53: 1676-1684, 2011.

25. Taatjes DJ: The human Mediator complex: a versatile, genome-wide regulator of transcription. Trends Biochem Sci 35: 315-322, 2010.

26. Moses H and Barcellos-Hoff MH: TGF-beta biology in mammary development and breast cancer. Cold Spring Harbor Perspect Biol 3: a003277, 2011.

27. Wiercinska E, Naber HP, Pardali E, van der Pluijm G, van Dam H and ten Dijke P: The TGF- $\beta /$ Smad pathway induces breast cancer cell invasion through the up-regulation of matrix metalloproteinase 2 and 9 in a spheroid invasion model system. Breast Cancer Res Treat 128: 657-666, 2011.

28. Petersen M, Pardali E, Van Der Horst G, Cheung H, van den Hoogen C, van der Pluijm G and Ten Dijke P: Smad2 and Smad3 have opposing roles in breast cancer bone metastasis by differentially affecting tumor angiogenesis. Oncogene 29: $1351-1361,2010$

29. Dzwonek J, Preobrazhenska O, Cazzola S, Conidi A, Schellens A, van Dinther M, Stubbs A, Klippel A, Huylebroeck D, ten Dijke P and Verschueren $\mathrm{K}$ : Smad3 is a key nonredundant mediator of transforming growth factor beta signaling in Nme mouse mammary epithelial cells. Mol Cancer Res 7: 1342-1353, 2009.

30. Szatrowski TP and Nathan CF: Production of large amounts of hydrogen peroxide by human tumor cells. Cancer Res 51: 794-798, 1991

31. Bierie B and Moses HL: Gain or loss of TGFbeta signaling in mammary carcinoma cells can promote metastasis. Cell Cycle 8: 3319-3327, 2009.

32. Bierie B, Chung CH, Parker JS, Stover DG, Cheng N, Chytil A, Aakre M, Shyr Y and Moses HL: Abrogation of TGF-beta signaling enhances chemokine production and correlates with prognosis in human breast cancer. J Clin Invest 119: 1571-1582, 2009.

33. Yang L, Huang J, Ren X, Gorska AE, Chytil A, Aakre M, Carbone DP, Matrisian LM, Richmond A, Lin PC and Moses HL: Abrogation of TGF beta signaling in mammary carcinomas recruits $\mathrm{Gr}-1+\mathrm{CD} 11 \mathrm{~b}+$ myeloid cells that promote metastasis. Cancer Cell 13: 23-35, 2008.

34. Giannelli G, Mazzocca A, Fransvea E, Lahn M and Antonaci S: Inhibiting TGF- $\beta$ signaling in hepatocellular carcinoma. Biochim Biophys Acta 1815: 214-223, 2011.

35. Aon MA, Cortassa S and O'Rourke B: Redox-optimized ROS balance: a unifying hypothesis. Biochim Biophys Acta 1797: 865-877, 2010.

36. Parga J, Rodríguez-Pallares J, Joglar B, Diaz-Ruiz C, Guerra M and Labandeira-Garcia JL: Effect of inhibitors of NADPH oxidase complex and mitochondrial ATP-sensitive potassium channels on generation of dopaminergic neurons from neurospheres of mesencephalic precursors. Dev Dyn 239: 3247-3259, 2010.

37. Li S, Tabar SS, Malec V, Eul BG, Klepetko W, Weissmann N, Grimminger F, Seeger W, Rose F, and Hänze J: NOX4 regulates ROS levels under normoxic and hypoxic conditions, triggers proliferation, and inhibits apoptosis in pulmonary artery adventitial fibroblasts. Antioxid Redox Signal 10: 1687-1698, 2008.

38. Liu RM, Choi J, Wu JH, Gaston Pravia KA, Lewis KM, Brand JD, Mochel NS, Krzywanski DM, Lambeth JD, Hagood JS, et al: Oxidative modification of nuclear mitogen-activated protein kinase phosphatase 1 is involved in transforming growth factor betal-induced expression of plasminogen activator inhibitor 1 in fibroblasts. J Biol Chem 285: 16239-16247, 2010

39. Liu R-M and Gaston Pravia K: Oxidative stress and glutathione in TGF- $\beta$-mediated fibrogenesis. Free Radic Biol Med 48: 1-15, 2010.

40. Hecker L, Vittal R, Jones T, Jagirdar R, Luckhardt TR, Horowitz JC, Pennathur S, Martinez FJ and Thannickal VJ: NADPH oxidase-4 mediates myofibroblast activation and fibrogenic responses to lung injury. Nat Med 15: 1077-1081, 2009. 